\title{
Correction to: Working to increase stability through exercise (WISE): screening, recruitment, and baseline characteristics
}

Christopher N. Sciamanna ${ }^{1 *}$, Noel H. Ballentine ${ }^{2}$, Melissa Bopp ${ }^{3}$, Vernon M. Chinchilli², Joseph T. Ciccolo ${ }^{4}$, Gabrielle Delauter², Abigail Fisher², Edward J. Fox², Suzanne M. Jan De Beur ${ }^{5}$, Kalen Kearcher², Jennifer L. Kraschnewski², Erik Lehman², Kathleen M. McTigue ${ }^{6}$, Edward McAuley ${ }^{7}$ Anuradha Paranjape ${ }^{8}$, Sol Rodriguez-Colon², Liza S. Rovniak², Kayla Rutt ${ }^{2}$, Joshua M. Smyth ${ }^{3}$, Kerry J. Stewart ${ }^{5}$, Heather L. Stuckey ${ }^{2}$ and Annie Tsay ${ }^{2}$

Correction to: Trials 17:809 (2021).

https://doi.org/10.1186/s13063-021-05761-0

Following the publication of the original article [1], we were notified of an error in last author's name.

Originally published name: Anne Tsay.

Corrected name: Annie Tsay.

The original article has been corrected.

\section{Author details}

'Department of Medicine, Division of General Internal Medicine, Penn State College of Medicine, Box HO34, 500 University Drive, Hershey, PA 17033, USA. ${ }^{2}$ Penn State College of Medicine, Hershey, USA. ${ }^{3}$ Penn State University, State College, USA. ${ }^{4}$ Columbia University, New York City, USA. ${ }^{5}$ Johns Hopkins University, Baltimore, USA. ${ }^{6}$ University of Pittsburgh, Pittsburgh, USA. ${ }^{7}$ nniversity of Illinois, Urbana, USA. ${ }^{8}$ Temple University, Philadelphia, USA.

Published online: 14 January 2022

\section{Reference}

1. Sciamanna CN, et al. Working to Increase Stability through Exercise (WISE): screening, recruitment, and baseline characteristics. Trials. 2021;22:809. https://doi.org/10.1186/s13063-021-05761-0.

The original article can be found online at https://doi.org/10.1186/s13063021-05761-0

* Correspondence: cs19081@gmail.com

${ }^{1}$ Department of Medicine, Division of General Internal Medicine, Penn State College of Medicine, Box HO34, 500 University Drive, Hershey, PA 17033, USA Full list of author information is available at the end of the article

(c) The Author(s). 2022 Open Access This article is licensed under a Creative Commons Attribution 4.0 International License, which permits use, sharing, adaptation, distribution and reproduction in any medium or format, as long as you give appropriate credit to the original author(s) and the source, provide a link to the Creative Commons licence, and indicate if changes were made. The images or other third party material in this article are included in the article's Creative Commons licence, unless indicated otherwise in a credit line to the material. If material is not included in the article's Creative Commons licence and your intended use is not permitted by statutory regulation or exceeds the permitted use, you will need to obtain permission directly from the copyright holder. To view a copy of this licence, visit http://creativecommons.org/licenses/by/4.0/ The Creative Commons Public Domain Dedication waiver (http://creativecommons.org/publicdomain/zero/1.0/) applies to the data made available in this article, unless otherwise stated in a credit line to the data. 